\title{
THE EFFECTS OF EARLY HARVESTING ON THE SEED VIGOUR OF THREE CORN (ZEA MAYS L.) HYBRIDS BASED ON GERMINATION CHARACTERISTICS
}

\author{
KONUȘKAN, Ö..$^{*}$ - GÖZÜBENLI, H. ${ }^{1}$ - BARUTÇULAR, C. ${ }^{2}-$ HOSSAIN, A. ${ }^{3}-$ ISLAM, M. S. ${ }^{4}-$ EL \\ SABAGH, A. ${ }^{5,6^{*}}$ \\ ${ }^{1}$ Department of Field Crops, Faculty of Agriculture, Mustafa Kemal University, Hatay, Turkey \\ (ORCID: 0000-0003-1135-2346-Ö. Konuşkan; 0000-0003-4799-5749-H. Gözübenli) \\ ${ }^{2}$ Department of Field Crops, Faculty of Agriculture, Cukurova University, Adana, Turkey \\ (ORCID: 000-0003-3583-9191) \\ ${ }^{3}$ Bangladesh Wheat and Maize Research Institute, Dinajpur 5200, Bangladesh \\ (ORCID: 0000-0003-0264-2712) \\ ${ }^{4}$ Department of Agronomy, Hajee Mohammad Danesh Science and Technology University, \\ Dinajpur 5200, Bangladesh \\ ${ }^{5}$ Department of Field Crops, Faculty of Agriculture, Siirt University, Turkey \\ ${ }^{6}$ Department of Agronomy, Faculty of Agriculture, Kafrelsheikh University, Kafr Al Sheikh, Egypt \\ (ORCID: 0000-0002-4241-192X) \\ *Corresponding author \\ e-mail:aymanelsabagh@gmail.com,okonuskan@mku.edu.tr
}

(Received $31^{\text {st }}$ Aug 2020; accepted $18^{\text {th }}$ Dec 2020)

\begin{abstract}
Time of harvesting in the case of corn is a key factor that contributes to obtain high seed vigour. In the context, the study was conducted at the Agricultural Experimental Area of Mustafa Kemal University, Turkey $\left(36^{\circ} 15^{\prime} \mathrm{N}\right.$ and $\left.36^{\circ} 30^{\prime} \mathrm{E}\right)$, to evaluate the germination characteristics of three corn hybrids including 'Dekalp 6589 (FAO 700)', 'Cadiz (FAO 700)' and 'Bolson (FAO 600)'. In order to use them in the present experiment, seeds of the selected corn were harvested at 5 day intervals, starting from the milking stage (seed harvesting of all corn hybrids was done 30 days after tasseling) to physiological maturity stages. Data on 1000 grain weight (1000-GW), electrical conductivity (EC), germination ratio (GR), germination index (GI), accelerated aging test index (AATI), cold test, cold test germination index (CTGI), and cold test germination time (CTGT) significantly varied among the selected hybrids in response to harvesting at different times. When harvesting was done after 30 days of tasseling the dry matter in cultivar 'Cadiz' showed the lowest, while the cultivar 'Bolson' showed the maximum dry matter. The earliest black layer in the cultivar 'Dekalp 6589' was found after 50 days while in the other two hybrids it was recorded 5 days later (55 days). The techniques of the present study related to evaluation seed vigour by estimating and evaluating germination properties may be used in future research as well as by farmers in field conditions for sustainable corn production in the changing climate.

Keywords: electrical conductivity germination ratio, germination index, aging test index, cold test
\end{abstract}

\section{Introduction}

Corn (Zea mays L.) is one of the most important cereal crops grown across the globe due to its widespread adaptability (Ranum et al., 2014; FAO, 2018 and Molla et al., 2019). It is widely grown in various soil and climatic conditions due to its contribution and adaptability to other cereals in the world. It is broadly used for food, fodder, fuel, industrial raw materials as well as corn oil (Konuskan et al., 2017; EL Sabagh et al., 2018; 
Maqsood et al., 2020). It is suitable for human consumption due to the presence of unsaturated fatty acids (Abdelaal et al., 2017; Sariyev et al., 2020). Area and production of corn ranks third in world after wheat and rice. Besides these, it can play a glorious role in the economy of the country by feeding malnourished people as well as solving food problems. Therefore, corn should get priority considering the protein malnourishment of the people, because it encompasses more digestible protein than other cereals (Ahamed, 2010; Ahmed et al., 2020; EL Sabagh et al., 2020; Ghosh et al., 2020).

In recent years, numerous studies were devoted to the physiological responses of seed germination and seedlings stages to chilling or osmotic stress (Anosheh et al., 2014), but the ecological responses of the whole growing season remain largely unknown (Tian et al., 2014). Rapid and uniform field emergence is an important factor to achieve high yield to meet the growing demand for food (Rosegrant et al., 1995). Naturally, the plant employs several adaptive measures to cope with harsh environments, such adaptive measures bring about changes or adjustments in the physiological and biochemical processes of the plant (EL Sabagh et al., 2018; Iqbal et al., 2021).

Seed quality is generally reflected by seed vigour that refers to the total properties of seed activities from germination under wider environments for storage longevity of seeds ( $\mathrm{Gu}$ et al., 2017), that determines the potential for fast and uniform seedling emergence (Woltz and TeKrony, 2001; Mondo et al., 2013), and development of vigorous seedlings under a widespread field conditions (AOSA, 1983, 2002). Generally, low germination speed and high sensibility of seed and seedlings face to various stresses during the germination process, lead to irregular shoot and root growth that ultimately leads to decrease in the productivity (Marcos-Filho, 2005).

Since seed harvesting at the optimum time is the vital factor that involves to achieve high seed vigour. During the maturation process, several morphological and physiological changes occur which are linked with seed vigour. Harvesting at a suitable time is a key factor that contributes to get seeds with high vigour (Gu et al., 2017) through maintaining the optimum quality. Harvesting too early leads to immature seeds that produce poor vigour ( $\mathrm{Fu}$ et al., 2017). The parameters frequently used are black layer formation, milk line development, seed weight (usually expressed as hundred-seed weight, HSW) and seed moisture content (SMC) (Afuakwa and Crookston, 1984; dos Santos et al., 2005). Both black layer formation and milk-line development stages were found the best seed harvesting time of corn for achieving the maximum high vigour of seeds through maintaining the best physiological quality (Gu et al., 2017). However, several scientists argued that the above-mentioned indicators are not always appropriate since these factors are sometime varied due to genetic makeup of a specific genotype and also their interaction with growing environments (Carter and Poneleit, 1973; Kinittle and Burris, 1976; Ma and Dwyer, 2001). Besides these, in classical breeding studies, selfing can be made only one time in a year. In the tropical and sub-tropical areas, there can be two times a year for selfing and harvesting. However, the seeds should be dried up quickly and sown again after the first self-seed. Thus classical breeding period will be halved.

Considering the above-mentioned limitations, scientists suggested some parameters such as 1000 grain weight (1000-GW), electrical conductivity (EC), germination ratio (GR), germination index (GI), accelerated aging test index (AATI), cold test, cold test germination index (CTGI), and cold test germination time (CTGT) are considered the most widely used parameters for determining seed vigour (ISTA, 2015; Gu et al., 2017), when they achieved maximum weight (also called physiological maturity, PM) (Wych, 
1988; TeKrony and Hunter, 1995). For avoiding elevated stress in seedbed at a minimum acceptable vigour level of $\geq 80 \%$, cold and accelerated aging tests are accurately used to optimize the field emergence of seeds (Woltz and TeKrony, 2001). In the context, the recent study was undertaken to determine the seed vigour of early harvesting of three corn (Zea mays L.) hybrids through observing several germination characteristics.

\section{Materials and methods}

\section{Location of the research}

The current study was conducted at the Agricultural Experimental Area of Mustafa Kemal University, Hatay, Turkey (located at $36^{\circ} 15^{\prime} \mathrm{N}$ and $36^{\circ} 30^{\prime} \mathrm{E}$ ), during the year 2016, where corn was growing as the main crop. Typical Mediterranean climatic conditions prevail in the region. The soil of research area is clay loam having $\mathrm{pH}$ 7.7, where available phosphorus and organic matter content are low.

\section{Experimental procedure}

The size of each plot was $4 \mathrm{~m}$ in length and $5 \mathrm{~m}$ in width including plant stand (Intra row: $70 \mathrm{~cm}$, Inter row: $18 \mathrm{~cm}$ ). Three hybrid corn, namely 'Dekalp 6589 (FAO 700)', 'Cadiz (FAO 700)', and 'Bolson (FAO 600)' were used as experimental material in this study. Seeds of hybrid corns were sown on 10 April 2016. Before planting, mixed fertilizers including $\mathrm{N}, \mathrm{P}_{2} \mathrm{O}_{5}$, and $\mathrm{K}_{2} \mathrm{O}$ at 15-15-15 ratio were applied and mixed into the soil. After the V6 stage, nitrogen was applied at $20 \mathrm{~kg} \mathrm{ha}^{-1}$ as top-dressing. Plots were irrigated every 10-14 days from June to each cob harvesting time when nearly half of available soil water was consumed. Weed control and other agronomic measurements were done when necessary. When cob silk was determined to $2 \mathrm{~cm}$ length, it had been marked. Seeds harvesting of all corn hybrids was done 30 days after tasseling based on specific milk line, black layer and dry matter $\%$ of seeds in eight harvesting times (Table 1). About 10 cobs were harvested in each harvest time. The cobs were harvested for a few days. Seeds were split in two. Milk-line and dry matter were determined in some of them. The other part started the germination process straight away.

\section{Estimation of the germination characteristics to know seeds vigour of all hybrids}

Seed testing was done at the Seed Science Laboratory, Department of Field Crops, Faculty of Agriculture, Mustafa Kemal University, Turkey. All of the seeds were dried under laboratory conditions before starting the seed vigour and germination tests.

The accelerated aging test for all hybrid seeds was conducted according to AOSA (1983). Accelerated unites were placed in germination cabinets at $45{ }^{\circ} \mathrm{C}$ for $72 \mathrm{~h}$ after which the kernels were removed and subjected to the standard germination and other germination tests (Woltz and TeKrony, 2001). The electrical conductivity (EC) test was performed according to Wang et al. (1994). Measurement of soaked water was performed 72 hrs using a conductivity meter (Model HANNA HI 255 Combined Meter, Germany). Results were expressed in $\mu \mathrm{S} \mathrm{cm}^{-1} \mathrm{~g}^{-1}$ to take account of variability in seed weight among the seed lots. 
Table 1. Seed harvesting of all corn hybrids were done 30 days after tasseling (DAT) based on specific milk-line $(M L)$, black layer formation and dry matter \% of seed

\begin{tabular}{|c|c|c|c|c|c|c|c|c|c|c|}
\hline \multirow{2}{*}{$\begin{array}{c}\text { No of } \\
\text { harvesting } \\
\text { times }\end{array}$} & \multirow{2}{*}{$\begin{array}{c}\text { Harvest at } \\
\text { following } \\
\text { dates after } \\
\text { tasseling }\end{array}$} & \multicolumn{6}{|c|}{ Grain maturity stage of all hybrids } & \multicolumn{3}{|c|}{$\begin{array}{c}\text { Dry matter }(\mathrm{DM})(\%) \text { of all } \\
\text { hybrids }\end{array}$} \\
\hline & & $\begin{array}{l}\text { Dekalp } \\
6589\end{array}$ & $\begin{array}{c}\text { Days } \\
\text { required for } \\
\text { ML \& BL }\end{array}$ & Cadiz & $\begin{array}{c}\text { Days } \\
\text { required for } \\
\text { ML \& BL }\end{array}$ & Bolson & $\begin{array}{c}\text { Days } \\
\text { required for } \\
\text { ML \& BL }\end{array}$ & $\begin{array}{c}\text { Dekalp } \\
6589\end{array}$ & Cadiz & Bolson \\
\hline 1 & $19 / 07 / 2016$ & $1 / 4 \mathrm{ML}$ & 92 & - & & - & & 63 & - & - \\
\hline 2 & $23 / 07 / 2016$ & $1 / 2 \mathrm{ML}$ & 97 & $1 / 4 \mathrm{ML}$ & 96 & - & & 68 & 60 & - \\
\hline 3 & $27 / 07 / 2016$ & $3 / 4 \mathrm{ML}$ & 102 & $1 / 2 \mathrm{ML}$ & 101 & $1 / 4 \mathrm{ML}$ & 100 & 66 & 59 & 61 \\
\hline 4 & $01 / 08 / 2016$ & $3 / 4 \mathrm{ML}$ & 107 & $1 / 2 \mathrm{ML}$ & 106 & $1 / 3 \mathrm{ML}$ & 105 & 67 & 62 & 66 \\
\hline 5 & $04 / 08 / 2016$ & BL & 112 & $3 / 4 \mathrm{ML}$ & 111 & $3 / 4 \mathrm{ML}$ & 110 & 69 & 62.5 & 68 \\
\hline 6 & 08/08/2016 & - & & $1 / 5 \mathrm{ML}$ & 116 & BL & 115 & 73 & 65 & 71 \\
\hline 7 & $12 / 08 / 2016$ & - & & BL & 121 & - & & 76 & 70 & 77 \\
\hline 8 & $16 / 08 / 2016$ & - & & - & & - & & 80 & 71 & 77 \\
\hline 9 & $20 / 08 / 2016$ & - & & - & & - & & 84 & 81 & 82 \\
\hline 10 & $24 / 08 / 2016$ & - & & - & & - & & - & 85 & 82 \\
\hline
\end{tabular}

The seed germination ratio was measured according to ISTA (2008). Twenty-five seeds were placed on three layers of moist, non-toxic, germination paper (Anchor Paper Co., St. Paul, Minn.). The papers were rolled, placed in a plastic container $(21.5 \times 32.5$ $\times 5.5 \mathrm{~cm}$ ), and incubated in a dark germinator at $25^{\circ} \mathrm{C}$ for 10 days. The incubator (model ES120) was used for the germination test. A seed was considered germinated when the emerging radicle was at least $2 \mathrm{~mm}$ long.

\section{Cold test and its estimating procedure}

Soil obtained from the top $5 \mathrm{~cm}$ of a corn-field at the Agricultural Experimental site of Mustafa Kemal University, Turkey was used for the cold test. The soil was screened through a $5 \mathrm{~mm}$ sieve and $450 \mathrm{~g}$ dry soils were placed into $19 \times 6 \times 9.5 \mathrm{~cm}$ plastic containers. Four replications of 50 seeds from each treatment were planted in each plastic container and covered with $450 \mathrm{~g}$ dry soil. A calculated quantity of prechilled $\left(10{ }^{\circ} \mathrm{C}\right)$ distilled water was added to adjust the moisture content to $70 \%$ of water holding capacity $\left(227 \mathrm{ml}\right.$ water). The containers were then covered and incubated at $10{ }^{\circ} \mathrm{C}$ in darkness for 7 days. The containers then moved to a $25^{\circ} \mathrm{C}$ chamber with an altering light source (12 h light day $\left.^{-1}\right)$ for 4 days grow-out period and normal seedlings were counted for germination ratio. Seedlings were classified as strong or weak after 7 days as described by Fiala (1987).

\section{Cold germination index}

Cold germination index was determined according to Carpici et al. (2009), using the formula:

$$
\mathrm{GI}=\sum(\mathrm{Gi} / \mathrm{Tt})
$$

where, GI is germination index, Gi is the germinating seeds per day, Tt is counting days of germination time. 


\section{Cold germination time}

Cold germination time was recorded according to Ellis and Roberts (1980), using the following formula:

$$
\operatorname{MGT}=\Sigma(\mathrm{n} . \mathrm{D}) / \Sigma \mathrm{n}
$$

where, ' $n$ ' is the number of newly germinated seeds on each day and ' $D$ ' is the day of counting.

\section{Statistical analysis}

The data were analyzed by partitioning the total variance with the help of a computer using MSTAT-C program. The treatment means were compared using Duncan's Multiple Range Test (DMRT, 1955).

\section{Results and discussion}

\section{Analysis of variance (ANOVA) for germination parameters}

Table 2 represents the summary of the analysis of variance (ANOVA) for seed germination characteristics of all three corn cultivars. The result indicated that the lowest dry matter was determined in the Cadiz hybrid, while the highest dry matter was determined in the cultivars of 'Bolson' corn at the first harvesting time (30 days after tasseling). This may be from a different FAO (600) groups of Corn varieties.

Table 2. Analysis of variance (ANOVA) of some germination parameters

\begin{tabular}{c|c|c|c|c|c|c|c|c|c}
\hline Sources of variation & $\mathbf{D F}$ & $\mathbf{1 0 0 0 - G W}$ & $\mathbf{E C}$ & $\mathbf{G R}$ & $\mathbf{G I}$ & AAGI & CT & CTGI & CGT \\
\hline Corn hybrids (A) & 2 & $1191.3^{* *}$ & $799.7^{* *}$ & $14.6^{* *}$ & $22.2^{* *}$ & $84.9^{* *}$ & $145.8^{* *}$ & $93.7^{* *}$ & $58.0^{* *}$ \\
Harvesting times (B) & 8 & $239.4^{* *}$ & $122.5^{* *}$ & $127.5^{* *}$ & $135.8^{* *}$ & $30.9^{* *}$ & $21.91^{* *}$ & $35.1^{* *}$ & $14.9^{* *}$ \\
A X B & 16 & $19.4 * *$ & $12.1 * *$ & $28.2^{* *}$ & $29.0^{* *}$ & $12.8^{* *}$ & $19.18^{* *}$ & $25.8^{* *}$ & $11.5^{* *}$ \\
\hline CV (\%) & & 2.50 & 7.26 & 5.50 & 6.97 & 10.67 & 7.42 & 6.11 & 4.99 \\
\hline
\end{tabular}

*, **Significant at $\mathrm{P}<0.05$ and $\mathrm{P}<0.01$ levels respectively. DF: degree of freedom; CV (\%): coefficient of variation; 1000-GW: 1000 grain weight; EC: electrical conductivity; GR: germination ratio; GI: germination index; AAGI: accelerating aging test index; CT: cold test; CTGI: cold test germination index; CTGT: cold test germination time

The earliest black layer was found in 'Dekalp 6589' hybrid at 50 days. The black layer was determined at 55 days in other corn hybrids. But the period between flowering and physiological maturity was determined as 15 days in 'Bolson' hybrids, but the others were completed in 20-25 days (Tables 1 and 2). The analysis of variance (mean squares) of all investigated properties of germination rate, germination index, germination time, root length and root fresh weight in normal and aging seeds were found to be statistically significant regarding the corn hybrids and harvesting times (Table 3). It was also observed that there was a significant difference in the interaction between hybrids and harvesting times. Findings of Kapoor et al. (2010) reported that accelerated aging in cowpea seeds influenced the physiological aspects such as germination percentage and vigour index. Further, the reduction in seed viability, germination rate, and vigour is associated with biochemical changes (for example, decrease in soluble proteins and sugar content) related to seed aging (Rastegar et al., 2011). 
Table 3. Effects of corn hybrids on 1000-GW, EC, GR, GI, AAGI, CT, CGI and CGT of corn hybrids

\begin{tabular}{c|c|c|c|c|c|c|c|c}
\hline Cultivars & 1000-GW & EC & GR & GI & AAGI & CT & CTGI & CTGT \\
\hline Dekalp 6589 & $283.2 \mathrm{~b}$ & $10.22 \mathrm{~b}$ & $81.75 \mathrm{~b}$ & $9.31 \mathrm{c}$ & $6.62 \mathrm{~b}$ & $67.1 \mathrm{c}$ & $9.05 \mathrm{c}$ & $4.88 \mathrm{a}$ \\
Cadiz & $241.1 \mathrm{c}$ & $12.78 \mathrm{a}$ & $87.4 \mathrm{a}$ & $10.18 \mathrm{a}$ & $9.32 \mathrm{a}$ & $91.5 \mathrm{a}$ & $11.57 \mathrm{a}$ & $4.28 \mathrm{~b}$ \\
Bolson & $314.5 \mathrm{a}$ & $8.53 \mathrm{c}$ & $82.8 \mathrm{~b}$ & $9.70 \mathrm{~b}$ & $7.08 \mathrm{~b}$ & $75.1 \mathrm{~b}$ & $10.22 \mathrm{~b}$ & $4.30 \mathrm{~b}$ \\
\hline LSD $(5 \%)$ & 3.4 & 0.24 & 2.54 & 0.3 & 0.5 & 3.29 & 0.41 & 0.14 \\
\hline
\end{tabular}

1000-GW: 1000 grain weight; EC: electrical conductivity; GR: germination ratio; GI: germination index; AAGI: accelerating aging test index; CT: cold test

The letters in all parameters are indicating the significant differences according to the DMRT

\section{0-GW (g) and electrical conductivity $\left(\mu S \mathrm{~cm}^{-1} \mathrm{~g}^{-1}\right)$}

It was also observed that there was a significant difference between hybrids and harvesting times. After the accelerated aging test, the highest 1000-GW (314.5) was observed in 'Bolson' hybrid at different harvesting times (Table 3). However, the highest EC (12.78) was recorded in 'Cadiz' hybrid at different harvesting times (Table 3). The highest 1000-GW (315.2) was recorded at the 62th DAT (Tables 3 and 4). Electrical Conductivity (EC) was also significantly influenced by the harvesting times in this study. On the other hand, the highest EC value was recorded at the 30th DAT (Table 4). Interaction effects of variety $\mathrm{x}$ harvesting time on the $1000 \mathrm{GW}$ and electrical conductivity of corn hybrids were also varied significantly (Table 5). The maximum 1000-GW (333.7) was recorded at the 58th DAT in 'Bolson' corn hybrid, followed by 62th DAT in same corn hybrid (333.3). Whereas the maximum EC (17.84) was recorded at 30th DAT in 'Bolson' hybrid, followed by 'Dekalp 6589' (16.23) at the same harvesting time (30th DAT) (Table 5). The explanation for seed deterioration is that high temperature and moisture content reduce the seed quality and these parameters are the factors to predict the life spans of seeds confirmed by earlier finding of Roberts et al. (1973).

Table 4. Effects of harvesting times on 1000-GW, EC, GR, GI, AAGI, CT, CGI and CGT of corn hybrids

\begin{tabular}{|c|c|c|c|c|c|c|c|c|}
\hline $\begin{array}{c}\text { Harvest at } \\
\text { following DAT }\end{array}$ & $\begin{array}{c}\text { 1000-GW } \\
(\mathrm{g})\end{array}$ & 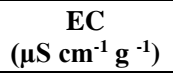 & GR $(\%)$ & GI & AAGI & CT (\%) & CTGI & CTGT (day) \\
\hline $30^{\text {th }}$ & $218.0 \mathrm{f}$ & $14.78 \mathrm{a}$ & $72.58 \mathrm{~d}$ & $8.32 \mathrm{~d}$ & $5.72 \mathrm{f}$ & $74.5 \mathrm{c}$ & $9.24 \mathrm{~cd}$ & $4.68 \mathrm{ab}$ \\
\hline $34^{\text {th }}$ & $247.1 \mathrm{e}$ & $13.43 \mathrm{~b}$ & $65.33 \mathrm{e}$ & $6.95 \mathrm{e}$ & $6.63 \mathrm{de}$ & $73.2 \mathrm{c}$ & $9.93 \mathrm{~b}$ & $4.50 \mathrm{c}$ \\
\hline $38^{\text {th }}$ & $266.1 \mathrm{~d}$ & $11.17 \mathrm{c}$ & $59.30 \mathrm{f}$ & $6.21 \mathrm{f}$ & $6.41 \mathrm{e}$ & $63.4 \mathrm{~d}$ & $8.96 \mathrm{~d}$ & $4.79 \mathrm{ab}$ \\
\hline $42^{\text {th }}$ & $281.7 \mathrm{c}$ & $10.73 \mathrm{c}$ & $84.50 \mathrm{c}$ & $8.87 \mathrm{~d}$ & $7.35 \mathrm{c}$ & $76.3 \mathrm{c}$ & $9.37 \mathrm{~cd}$ & $4.81 \mathrm{a}$ \\
\hline $46^{\text {th }}$ & $286.4 \mathrm{c}$ & $11.08 \mathrm{c}$ & $91.50 \mathrm{~b}$ & $10.28 \mathrm{c}$ & $7.28 \mathrm{~cd}$ & $74.2 \mathrm{c}$ & $9.52 \mathrm{bc}$ & $4.61 \mathrm{bc}$ \\
\hline $50^{\text {th }}$ & $298.0 \mathrm{~b}$ & $9.20 \mathrm{~d}$ & $97.30 \mathrm{a}$ & $11.58 \mathrm{~b}$ & $8.46 \mathrm{~b}$ & $89.0 \mathrm{a}$ & $11.14 \mathrm{a}$ & $4.28 \mathrm{~d}$ \\
\hline $54^{\text {th }}$ & $294.1 \mathrm{~b}$ & $8.67 \mathrm{~d}$ & $86.00 \mathrm{c}$ & $10.50 \mathrm{c}$ & $9.69 \mathrm{a}$ & $82.5 \mathrm{~b}$ & $11.32 \mathrm{a}$ & $4.28 \mathrm{~d}$ \\
\hline $58^{\text {th }}$ & $309.9 \mathrm{a}$ & $7.85 \mathrm{e}$ & $99.50 \mathrm{a}$ & $12.37 \mathrm{a}$ & $8.94 \mathrm{~b}$ & $86.2 \mathrm{ab}$ & $11.43 \mathrm{a}$ & $4.14 \mathrm{~d}$ \\
\hline $62^{\text {th }}$ & $315.2 \mathrm{a}$ & $7.71 \mathrm{e}$ & $99.80 \mathrm{a}$ & $12.48 \mathrm{a}$ & $8.59 \mathrm{~b}$ & $81.8 \mathrm{~b}$ & $1160 \mathrm{a}$ & $4.28 \mathrm{~d}$ \\
\hline $\operatorname{LSD}(5 \%)$ & 5.69 & 0.62 & 3.76 & 0.55 & 0.67 & 4.7 & 0.51 & 0.18 \\
\hline
\end{tabular}

\section{Germination time $(G T)$}

A significant variation of GT among treatments of all the corn hybrids was found due to the differences in harvest times (Table 5). The mean GT, under conditions providing aging were significant with accelerated aging of corn seed (Kapilan, 2015). 
Table 5. Interaction effects of corn hybrids $x$ harvesting time on the 1000-GW and electrical conductivity of corn hybrids

\begin{tabular}{|c|c|c|c|c|c|c|}
\hline \multirow{2}{*}{$\begin{array}{c}\text { Harvest at } \\
\text { following DAT }\end{array}$} & \multicolumn{3}{|c|}{$1000 \mathrm{GW}(\mathrm{g})$} & \multicolumn{3}{|c|}{$\mathrm{EC}\left(\mu \mathrm{S} \mathrm{cm} \mathrm{cm}^{-1} \mathrm{~g}^{-1}\right)$} \\
\hline & Dekalp 6589 & Cadiz & Bolson & Dekalp 6589 & Bolson & Cadiz \\
\hline $30^{\text {th }}$ & 202.1 op & $178.4 \mathrm{q}$ & 273.61 & $16.23 b$ & $17.84 \mathrm{a}$ & $10.23 \mathrm{fg}$ \\
\hline $34^{\text {th }}$ & $251.5 \mathrm{~m}$ & $194.2 \mathrm{p}$ & $295.6 \mathrm{gh}$ & $13.72 \mathrm{c}$ & $16.16 \mathrm{~b}$ & 10.39 ef \\
\hline $38^{\text {th }}$ & $288.7 \mathrm{~h}-\mathrm{k}$ & 204.5 o & $305.1 \mathrm{e}-\mathrm{g}$ & $10.15 \mathrm{f}-\mathrm{h}$ & $14.06 \mathrm{c}$ & $9.29 \mathrm{~g}-\mathrm{j}$ \\
\hline $42^{\text {th }}$ & $291.2 \mathrm{~h}-\mathrm{j}$ & $240.8 \mathrm{n}$ & $313.1 \mathrm{~d}-\mathrm{f}$ & 10. $00 \mathrm{f}-\mathrm{i}$ & $13.05 \mathrm{c}$ & 9.14 h-k \\
\hline $46^{\text {th }}$ & $292.5 \mathrm{hi}$ & $240.9 \mathrm{n}$ & $325.6 \mathrm{a}-\mathrm{c}$ & $8.971-1$ & $13.85 \mathrm{c}$ & $10.43 \mathrm{ef}$ \\
\hline $50^{\text {th }}$ & $284.1 \mathrm{i}-\mathrm{k}$ & $278.9 \mathrm{kl}$ & $330.9 \mathrm{ab}$ & $9.37 \mathrm{f}-\mathrm{j}$ & $11.55 \mathrm{~d}$ & $3.68 \mathrm{o}$ \\
\hline $54^{\text {th }}$ & $303.4 \mathrm{fg}$ & $259.4 \mathrm{~m}$ & $319.5 \mathrm{~cd}$ & $8.11 \mathrm{k}-\mathrm{n}$ & $11.44 \mathrm{de}$ & $6.45 \mathrm{o}$ \\
\hline $58^{\text {th }}$ & $314.0 \mathrm{de}$ & $282.1 \mathrm{j}-1$ & $333.7 \mathrm{a}$ & 7.13 no & $9.06 \mathrm{i}-\mathrm{k}$ & $7.38 \mathrm{~m}-\mathrm{o}$ \\
\hline $62^{\text {th }}$ & $321.5 \mathrm{bd}$ & 290.9 h-j & $333.3 \mathrm{a}$ & $8.31 \mathrm{j}-\mathrm{m}$ & $8.061-\mathrm{n}$ & $6.75 \mathrm{o}$ \\
\hline $\operatorname{LSD}(5 \%)$ & \multicolumn{3}{|c|}{9.86} & \multicolumn{3}{|c|}{1.07} \\
\hline
\end{tabular}

1000-GW: 1000 grain weight; EC: electrical conductivity

The letters in all parameters are indicating the significant differences according to the DMRT

Table 6. Interaction effects of corn hybrids $x$ harvesting times on the germination ratio and germination index of corn hybrids

\begin{tabular}{c|c|c|c|c|c|c}
\hline \multirow{2}{*}{$\begin{array}{c}\text { Harvest at } \\
\text { following DAT }\end{array}$} & \multicolumn{3}{|c|}{ Germination ratio (\%) } & \multicolumn{3}{c}{ Germination index } \\
\cline { 2 - 7 } & Dekalp 6589 & Cadiz & Bolson & Dekalp 6589 & Cadiz & Bolson \\
\hline $30^{\text {th }}$ & $87.2 \mathrm{c}$ & $83.5 \mathrm{~cd}$ & $47.0 \mathrm{i}$ & $9.92 \mathrm{de}$ & $10.39 \mathrm{~cd}$ & $4.66 \mathrm{i}$ \\
$34^{\text {th }}$ & $75.0 \mathrm{ef}$ & $69.0 \mathrm{fg}$ & $52.0 \mathrm{i}$ & $8.93 \mathrm{fg}$ & $7.1 \mathrm{~h}$ & $4.84 \mathrm{i}$ \\
$38^{\text {th }}$ & $50.0 \mathrm{i}$ & $66.0 \mathrm{gh}$ & $62.0 \mathrm{~h}$ & $4.75 \mathrm{i}$ & $7.15 \mathrm{~h}$ & $6.73 \mathrm{~h}$ \\
$42^{\text {th }}$ & $83.5 \mathrm{~cd}$ & $80.0 \mathrm{de}$ & $90.0 \mathrm{bc}$ & $8.21 \mathrm{~g}$ & $8.57 \mathrm{~g}$ & $9.83 \mathrm{~d}-\mathrm{f}$ \\
$46^{\text {th }}$ & $84.0 \mathrm{~cd}$ & $95.5 \mathrm{ab}$ & $95.0 \mathrm{ab}$ & $9.08 \mathrm{e}-\mathrm{g}$ & $10.15 \mathrm{~d}$ & $11.59 \mathrm{ab}$ \\
$50^{\text {th }}$ & $97.5 \mathrm{a}$ & $94.5 \mathrm{ab}$ & $100 \mathrm{a}$ & $11.26 \mathrm{bc}$ & $11.12 \mathrm{bc}$ & $12.35 \mathrm{a}$ \\
$54^{\text {th }}$ & $60.0 \mathrm{~h}$ & $99.0 \mathrm{a}$ & $99.0 \mathrm{a}$ & $6.90 \mathrm{~h}$ & $12.25 \mathrm{a}$ & $12.34 \mathrm{a}$ \\
$58^{\text {th }}$ & $99.0 \mathrm{a}$ & $99.5 \mathrm{a}$ & $100 \mathrm{a}$ & $12.22 \mathrm{a}$ & $12.44 \mathrm{a}$ & $12.48 \mathrm{a}$ \\
$62^{\text {th }}$ & $99.5 \mathrm{a}$ & $100 \mathrm{a}$ & $100 \mathrm{a}$ & $12.5 \mathrm{a}$ & $12.49 \mathrm{a}$ & $12.45 \mathrm{a}$ \\
\hline LSD $(5 \%)$ & \multicolumn{7}{|c|}{6.51} & & 0.96 &
\end{tabular}

1000-GW: 1000 grain weight; EC: electrical conductivity

The letters in all parameters are indicating the significant differences according to the DMRT

\section{Germination ratio}

Germination ratio (GR) is an important trait that influences the stand establishment and yield of crops. After accelerated aging test, the highest GR (75.25\%) was observed in 'Dekalp 6589' hybrid at different harvesting time of corn seeds followed by hybrids 'Cadiz' and 'Bolson' (Table 6). The GR was also significantly influenced by the harvesting times in this study. However, the highest GR $(78.00 \%)$ was recorded at the 40th DAT which was statistically identical with 35th and 55th DAT, while the lowest GR (21.00\%) was observed at 30th DAT. The germination ratio of different phenological stages has been reported in several earlier studies (Demir and Mavi, 2004; Demir and Mavi, 2008). 


\section{Germination index $(G I)$}

Corn hybrids faced significant variations in the germination index due to harvest times. The maximum values were determined at $58^{\text {th }}$ and $62^{\text {nd }}$ day in the case of the hybrid 'Dekalp 6589', but no significant differences were detectable between 54 to $62^{\text {nd }}$ harvest of hybrid 'Cadiz' or 46 to 62 days of hybrid 'Bolson' through estimation of GI (Table 6). Ghassemi-Golezani et al. (2010) reported that the reduction in germination percent and other indices can be due to physiological and biochemical changes during seed aging.

\section{Accelerated aging test index (AAGI) and cold test (CT)}

A significant variation of accelerated aging test index (AAGI) and cold test (CT) among treatments of all corn hybrids were found when grown upto the harvest times (Table 7). The AAGI was also significantly influenced by the harvesting times in this study. However, the highest AAGI (9.32a) was recorded in 'Cadiz' hybrid at different harvesting times (Table 3), and the highest AAGI (9.69 a) was recorded at the 54th DAT (Table 4). The reduction of AAGI with aging seed was due to the increase in respiration in the cell during the process to prevent cell damage as confirmed by earlier findings of Torres and Andrews (2006) and Vashisth and Nagarajan (2009). Among the corn hybrids, the maximum CT (91.5) was documented in the cultivar 'Cadiz', while the highest value (89.0) was observed at the harvesting time of 50th DAT. The rate of deterioration of seeds depends on storage conditions such as temperature, atmospheric moisture and oxygen concentration (confirmed by Walters et al., 2005).

Table 7. Interaction effects of corn hybrids $x$ harvesting times on the AAGI and CT of corn hybrids

\begin{tabular}{c|c|c|c|c|c|c}
\hline \multirow{2}{*}{$\begin{array}{c}\text { Harvest at } \\
\text { following DAT }\end{array}$} & \multicolumn{5}{|c|}{ AAGI } & \multicolumn{3}{c}{ CT (\%) } \\
\cline { 2 - 7 } & Dekalb 6589 & Bolson & Cadiz & Dekalb 6589 & Cadiz & Bolson \\
\hline $30^{\text {th }}$ & $6.08 \mathrm{~g}-\mathrm{j}$ & $5.64 \mathrm{~h}-\mathrm{j}$ & $5.44 \mathrm{ij}$ & $76.0 \mathrm{hi}$ & $86.0 \mathrm{c}-\mathrm{g}$ & $61.5 \mathrm{j}$ \\
$34^{\text {th }}$ & $6.09 \mathrm{~g}-\mathrm{j}$ & $8.26 \mathrm{c}-\mathrm{e}$ & $5.55 \mathrm{~h}-\mathrm{j}$ & $64.0 \mathrm{j}$ & $93.0 \mathrm{a}-\mathrm{c}$ & $62.5 \mathrm{j}$ \\
$38^{\text {th }}$ & $9.42 \mathrm{~d}-\mathrm{f}$ & $5.19 \mathrm{j}$ & $6.62 \mathrm{f}-\mathrm{h}$ & $48.3 \mathrm{k}$ & $89.0 \mathrm{a}-\mathrm{e}$ & $53.0 \mathrm{k}$ \\
$42^{\text {th }}$ & $5.34 \mathrm{ij}$ & $9.29 \mathrm{bc}$ & $7.47 \mathrm{~d}-\mathrm{f}$ & $51.0 \mathrm{k}$ & $95.0 \mathrm{ab}$ & $83.0 \mathrm{~d}-\mathrm{h}$ \\
$46^{\text {th }}$ & $6.27 \mathrm{~g}-\mathrm{j}$ & $9.56 \mathrm{~b}$ & $6.03 \mathrm{~g}-\mathrm{j}$ & 38.01 & $96.5 \mathrm{a}$ & $88.0 \mathrm{~b}-\mathrm{f}$ \\
$50^{\text {th }}$ & $6.48 \mathrm{f}-\mathrm{i}$ & $11.75 \mathrm{a}$ & $7.13 \mathrm{e}-\mathrm{g}$ & $82.0 \mathrm{e}-\mathrm{h}$ & $97.0 \mathrm{a}$ & $88.0 \mathrm{~b}-\mathrm{f}$ \\
$54^{\text {th }}$ & $9.50 \mathrm{~b}$ & $10.98 \mathrm{a}$ & $8.57 \mathrm{~b}-\mathrm{d}$ & $73.5 \mathrm{i}$ & $95.5 \mathrm{ab}$ & $78.5 \mathrm{~g}-\mathrm{i}$ \\
$58^{\text {th }}$ & $6.81 \mathrm{fg}$ & $11.33 \mathrm{a}$ & $8.69 \mathrm{bc}$ & $86.5 \mathrm{c}-\mathrm{g}$ & $90.5 \mathrm{a}-\mathrm{d}$ & $81.5 \mathrm{e}-\mathrm{i}$ \\
$62^{\text {th }}$ & $5.63 \mathrm{~h}-\mathrm{j}$ & $11.89 \mathrm{a}$ & $8.26 \mathrm{c}-\mathrm{e}$ & $84.5 \mathrm{~d}-\mathrm{g}$ & $81.0 \mathrm{e}-\mathrm{i}$ & $80.0 \mathrm{f}-\mathrm{i}$ \\
\hline LSD $(5 \%)$ & \multicolumn{7}{|l}{} & & & \\
\hline
\end{tabular}

AAGI: accelerating aging test index; CT: cold test

The letters in all parameters are indicating the significant differences according to the DMRT

\section{Cold test germination index (CTGI), and cold test germination time (CTGT)}

A significant difference was observed among the hybrids and harvesting times after the accelerated aging test. The highest CTGI (12.38) was observed in the corn hybrid 'Bolson' at different harvesting times and was recorded at the 54th DAT (Table 8). The CTGT was also significantly influenced by the harvesting times in this study. However, 
the highest CTGT (5.92) was recorded in 'Dekalp 6589'hybrid at the 42nd DAT, while the lowest (4.03) was recorded in the hybrid 'Bolson' at 54th DAT (Table 8).

Table 8. Interaction effects of corn hybrids $x$ harvesting times on the CTGI, and CTGT of corn hybrids

\begin{tabular}{c|c|c|c|c|c|c}
\hline \multirow{2}{*}{$\begin{array}{c}\text { Harvest at } \\
\text { following DAT }\end{array}$} & \multicolumn{3}{|c|}{ CTGI } & \multicolumn{3}{c}{ CTGT (day) } \\
\cline { 2 - 6 } & Dekalp 6589 & Bolson & Cadiz & Dekalp 6589 & Bolson & Cadiz \\
\hline $30^{\text {th }}$ & $8.68 \mathrm{jk}$ & $10.98 \mathrm{e}-\mathrm{g}$ & $8.06 \mathrm{k}-\mathrm{m}$ & $5.29 \mathrm{~b}$ & $4.55 \mathrm{de}$ & $4.22 \mathrm{f}-\mathrm{j}$ \\
$34^{\text {th }}$ & $10.09 \mathrm{~g}-\mathrm{i}$ & $11.43 \mathrm{~b}-\mathrm{f}$ & $8.27 \mathrm{~km}$ & $4.63 \mathrm{~d}$ & $4.46 \mathrm{~d}-\mathrm{f}$ & $4.41 \mathrm{~d}-\mathrm{h}$ \\
$38^{\text {th }}$ & $7.38 \mathrm{~lm}$ & $12.15 \mathrm{ab}$ & $7.34 \mathrm{~m}$ & $5.29 \mathrm{~b}$ & $4.11 \mathrm{~h}-\mathrm{j}$ & $4.96 \mathrm{c}$ \\
$42^{\text {th }}$ & $6.01 \mathrm{n}$ & $11.52 \mathrm{a}-\mathrm{e}$ & $10.57 \mathrm{f}-\mathrm{h}$ & $5.92 \mathrm{a}$ & $4.24 \mathrm{e}-\mathrm{j}$ & $4.27 \mathrm{e}-\mathrm{j}$ \\
$46^{\text {th }}$ & $5.96 \mathrm{n}$ & $11.23 \mathrm{c}-\mathrm{f}$ & $11.38 \mathrm{~b}-\mathrm{f}$ & $5.35 \mathrm{~b}$ & $4.40 \mathrm{~d}-\mathrm{h}$ & $4.08 \mathrm{ij}$ \\
$50^{\text {th }}$ & $10.09 \mathrm{hi}$ & $11.88 \mathrm{a}-\mathrm{d}$ & $11.45 \mathrm{~b}-\mathrm{f}$ & $4.43 \mathrm{~d}-\mathrm{g}$ & $4.27 \mathrm{e}-\mathrm{j}$ & $4.14 \mathrm{~g}-\mathrm{j}$ \\
$54^{\text {th }}$ & $9.40 \mathrm{ij}$ & $12.38 \mathrm{a}$ & $12.18 \mathrm{ab}$ & $4.66 \mathrm{~cd}$ & $4.03 \mathrm{j}$ & $4.15 \mathrm{f}-\mathrm{j}$ \\
$58^{\text {th }}$ & $11.8 \mathrm{a}-\mathrm{e}$ & $11.38 \mathrm{~b}-\mathrm{f}$ & $11.13 \mathrm{~d}-\mathrm{f}$ & $4.16 \mathrm{f}-\mathrm{j}$ & $4.08 \mathrm{ij}$ & $4.18 \mathrm{f}-\mathrm{j}$ \\
$62^{\text {th }}$ & $12.05 \mathrm{a}-\mathrm{c}$ & $11.18 \mathrm{c}-\mathrm{f}$ & $11.57 \mathrm{a}-\mathrm{e}$ & $4.16 \mathrm{f}-\mathrm{j}$ & $4.38 \mathrm{di}$ & $4.29 \mathrm{e}-\mathrm{j}$ \\
\hline LSD $(5 \%)$ & \multicolumn{5}{|c}{0.32} \\
\hline
\end{tabular}

The letters in all parameters are indicating the significant differences according to the DMRT

\section{Conclusion}

From the above results and discussion of the present study, it can be concluded that germinating properties such as 1000-GW, EC, GR, GI, AATI, CTGI, and CTGT may be used potentially for the evaluation of seed vigour. Among these tested corn hybrids, seeds harvested from hybrid 'Cadiz' showed the lowest dry matter and the highest other parameters during the first harvesting (20 DAT). Considering the milk-line and black layer formation, the earliest black layer (at 50 DAT) was found in the hybrid 'Dekalp 6589', but for the other two hybrids, the black layer was recorded at 55 DAT, indicating that the seed vigour of hybrid 'Cadiz' is better than that of the others. The techniques of the present study related to evaluation seed vigour by estimating and evaluating germination properties may be useful in future research as well as by farmers' field for sustainable corn production in the changing climate.

Conflict of interests. The authors declare that there is no conflict of interests regarding the publication of this paper.

\section{REFERENCES}

[1] Abdelaal, K. A. A., Hafez, Y. M., EL Sabagh, A., Saneoka, H. (2017): Ameliorative effects of Abscisic acid and yeast on morpho-physiological and yield characteristics of maize plant (Zea mays L.) under water deficit conditions. - Fresenius Environ. Bull. 26(12): 7372-7383.

[2] Afuakwa, J. J., Crookston, R. K. (1984): Using the kernel milk line to visually monitor grain maturity in maize. - Crop Sci. 24: 687-691. DOI: 10.2135/cropsci1984.0011183X $002400040015 x$.

[3] Ahamed, K. U. (2010): Efficacy of indigenous mulches on the maize-pulse association. Ph.D. Thesis, Department of Crop Botany, Bangladesh Agricultural University, Mymensingh, Bangladesh.

[4] Ahmed, A., Hossain, A., Amiruzzaman, M., Alam, M. A., Farooq, M., EL Sabagh, A., Kizilgeci, F. (2020): Evaluating Short Stature And High Yielding Maize Hybrids In Multiple Environments Using Gge Biplot And Ammi Models. - Turkish Journal of Field Crops 25(2): $216-226$. 
[5] Anosheh, H. P., Emam, Y., Ashraf, M. (2014): Impact of cycocel on seed germination and growth in some commercial crops under osmotic stress conditions. - Archives of Agron. Soil Sci. 60(9): 1277-1289.

[6] Association of Official Seed Analysts (AOSA) (1983): Seed Vigor Testing Handbook. (Contribution to the Handbook on Seed Testing, 32). - AOSA, Ithaca, NY.

[7] Association of Official Seed Analysts (AOSA) (2002): Seed Vigor Testing Handbook. (Contribution, 32) - AOSA, Ithaca, NY.

[8] Carpici, E. B., Celik, N., Bayram, G. (2009): Effects of salt stress on germination of some maize (Zea mays L.) cultivars. - Afr. J. Biotechnol. 8: 4918-4922.

[9] Demir, İ., Mavi, K. (2004): The effect of priming on seedling emergence of differentially matured watermelon (Citrullus lanatus (Thunb.) Matsum and Nakai) seeds. - Sci. Hort. 102(4): 467-473.

[10] Demir, İ., Mavi, K. (2008): Effect of salt and osmotic stresses on the germination of pepper seeds of different maturation stages. - Brazilian Arc. Biol. Technol. 51(5): 897902.

[11] dos Santos, C. T., Dalpasquale, V. A., Scapim, C. A., Braccini, A. L., Krzyzanowski, F. C. (2005): Milk line as an indicator of the harvesting time of three hybrid seeds of corn (Zea mays L.). - Braz. Arch. Biol. Tech. 48: 161-170. DOI: 10.1590/S1516-89132005000 200001.

[12] EL Sabagh et al. (2020): Maize Adaptability to Heat Stress under Changing Climate. IntechOpen, London. https://www.intechopen.com/online-first/maize-adaptability-toheat-stress-under-changing-climate. DOI: 10.5772/intechopen.92396.

[13] EL Sabagh, A., Barutçular, C., Hossain, A., Islam, M. S. (2018): Response of maize hybrids to drought tolerance indices in relation to grain weight. - Frese. Environ. Bull. 27(4): 2476-2482.

[14] Ellis, R. H., Roberts, E. H. (1980): Towards Rational Basis for Testing Seed Quality. Hebblethwaite, P. D. (ed.) Seed Production. Butterworths, London, pp. 605-635.

[15] FAO (Food and Agriculture Organization) (2018): FAOSTAT, Food Supply. http://www.fao.org/faostat/en/\#data (accessed 2018 Oct 05).

[16] Fiala, F. (1987): Handbook of Vigour Test Methods. - International Seed Testing Association, Zurich.

[17] Fu, H., Cao, D. D., Hu, W. M., Guan, Y. J., Fu, Y. Y., Fang, Y. F., Hu, J. (2017): Studies on optimum harvesting time for hybrid rice seed. - J. Sci. Food Agric. 97: 1124-1133.

[18] Ghassemi-Golezani, K., Khomari, S., Dalili, B., Hosseinzadeh-Mahootchy, B., Chadordooz-Jedi, A. (2010): Effect of seed aging on field performance of winter oil seed rape. - J. Food Agric. Environ. 8(1): 175-178.

[19] Ghosh, D., Brahmachari, K., Skalicky, M., Hossain, A., Sarkar, S., Dinda, N.K., Das, A., Pramanick, B., Moulick, D., Brestic, M., Raza, M.A., Barutcular, C., Fahad, S., Saneoka, H., EL Sabagh, A. (2020): Nutrients Supplementation through Organic Manures Influence the Growth of Weeds and Maize Productivity. - Molecules 25(21):4924. https://doi.org/10.3390/molecules25214924

[20] Gu, R., Li, L., Liang, X., Wang, Y., Fan, T., Wang, Y., Wang, J., Gu, R., Li, L., Liang, X., Wang, Y., Fan, T., Wang, Y. (2017): The ideal harvesting time for seeds of hybrid maize (Zea mays L.) XY335 and ZD958 produced in multiple environments. - Sci. Rep. 7: 17537. DOI: 10.1038/s41598-017-16071-4.

[21] Iqbal, A., Iqbal, M.A., Awad, M.F., Nasir, M., EL Sabagh, A., Siddiqui, M.H. (2021): Spatial arrangements and seeding rates influence biomass productivity, nutritional value and economic viability of maize (Zea mays L.). - Pak. J. Bot. 53(3). DOI: http://dx.doi.org/10.30848/PJB2021-3(44)

[22] ISTA (2008): International Rules for Seed Testing. - International Seed Testing Association, Bassersdorf.

[23] ISTA (2015): International Rules for Seed Testing. - International Seed Testing Association (ISTA), Zurich. 
[24] Kapilan, R. (2015): Accelerated aging declines the germination characteristics of the maize seeds. - Sch. Acad. J. Biosci. 3(8): 708-711.

[25] Kapoor, N., Arya, A., Siddiqui, M. A., Amir, A., Kumar, H. (2010): Seed deterioration in chickpea (Cicer arietinum L.) under accelerated aging. - Asian J. Plant Sci. 9(3): 158162.

[26] Kinittle, K. H., Burris, J. S. (1976): Effect of kernel maturation on subsequent seedling vigor in maize. - Crop Sci. 16: 851-854. DOI: 10.2135/cropsci1976.0011183X 001600060030x.

[27] Konuskan, O., Konuskan Bozdogan, D., Levai, C. M. (2017): Effect of foliar boron fertilization on chemical propeties and fatty acid composition of corn (Zea mays L). Rev. Chim. (Burcherest) 68(9): 2073-2075.

[28] Ma, B. L., Dwyer, L. M. (2001): Maize kernel moisture, carbon and nitrogen concentrations from silking to physiological maturity. - Can. J. Plant Sci. 81: 225-232. DOI: $10.4141 / \mathrm{P} 00-073$.

[29] Maqsood, Q., Abbas, R.N., Iqbal, A.M., Serap, A. K., Iqbal, A., EL Sabagh, A. (2020): Overviewing of weed management practices to reduce weed seed bank and to increase maize yield. - Planta Daninha, 38.

[30] Marcos-Filho, J. (2005): Fisiologia de sementes de plantas cultivadas. - FEALQ, Piracicaba.

[31] Molla, S. H., Sutkhet, N., Ali, M. A., Khan, A. S. M. M. R., Alam, M. R., Hossain, A., Farooq, M., EL Sabagh, A. (2019): Influence of nitrogen application on dry biomass allocation and translocation in two maize varieties under short pre-anthesis and prolonged bracketing flowering periods of drought. - Arch. Agron. Soil Sci. 65(7): 928-944.

[32] Mondo, V. H. V., Cicero, S. M., Dourado-Neto, D., Pupim, T. L., Dias, M. A. N. (2013): Seed vigor and initial growth of corn crop. - J. Seed Sci. 35(1): 64-69.

[33] Ranum, P., Peña-Rosas, J. P., Garcia-Casal, M. N. (2014): Global maize production, utilization, and consumption. - Ann. New York Acad Sci. 1312: 105-112.

[34] Rastegar, Z., Sedghi, M., Khomari, S. (2011): Effects of accelerated aging on soybean seed germination indexes at laboratory conditions. - Not. Sci. Biol. 3: 126.

[35] Roberts, B. E., Payne, P. I.,Osborne, D. J. (1973): Protein synthesis and the viability of rye grains: Loss of activity of protein-synthesizing systems in vitro associated with a loss of viability. - Biochem. J. 131: 275-286.

[36] Rosegrant, M. W., Agcaoili-Sombilla, M., Perez, N. D. (1995): Food, Agriculture and the Environment Discussion Paper 5. Global Food Projections to 2020: Implications for Investment. - IFPRI, Washington, DC.

[37] Sariyev, A., Barutcular, C., Acar, M., Hossain, A., EL Sabagh, A. (2020): Sub-surface drip irrigation in associated with $\mathrm{H} 2 \mathrm{O} 2$ improved the productivity of maize under clayrich soil of Adana, Turkey. - Phyton 89:519.

[38] TeKrony, D. M., Hunter, J. L. (1995): Effect of seed maturation and genotype on seed vigor in maize. - Crop Sci. 35: 857-862. DOI: 10.2135/cropsci1995.0011183 $\mathrm{X} 003500030037 \mathrm{x}$.

[39] Tian, Y., Guan, B., Zhou, D., Yu, J., Li, G., Lou, Y. (2014): Responses of seed germination, seedling growth, and seed yield traits to seed pretreatment in maize (Zea mays L.). - Sci. World J. 834630.

[40] Torres, C. A., Andrews, P. K. (2006): Developmental changes in antioxidant metabolites, enzymes and pigments in fruit exocarp of four tomato (Lycopersicon esculentum Mill.) genotypes: $\beta$-carotene, high pigment-1, ripening inhibitor and Rutgers. - Plant Physiol. Biochem. 44: 11-12.

[41] Vashisth, A., Nagarajan, S. (2009): Germination characteristics of seeds of maize (Zea mays L.) exposed to magnetic fields under accelerated ageing condition. - J. Agric. Physics 9: 50-58. 
[42] Walters, C., Hill, L. M., Wheeler, L. J. (2005): Dying while dry: kinetics and mechanisms of deterioration in desiccated organisms. - Integrative and Comparative Biology 45(5): 751-758. https://doi.org/10.1093/icb/45.5.751.

[43] Wang, Y. R., Hampton, J. G., Hill, M. J. (1994): Red clover vigor testing - effects of three test variables. - Seed Sci. Technol. 22: 99-105.

[44] Woltz, J. M., TeKrony, D. M. (2001): Accelerated aging test for corn seed. - Seed Technol. 23: 21-34.

[45] Wych, R. D. (1988): Production of Hybrid Seed Corn. - Sprague, G. F., Dudley, J. W. (eds.) Corn and Corn Improvement. ASA, Madison, WI, pp. 565-607. 